\title{
Range Extension of the Copper-headed Trinket Snake, Coelognathus radiatus (Boie 1827) (Squamata: Colubridae), from Himachal Pradesh, India
}

Vishal Varma and Fergus Mark Anthony

Wildlife Institute of India, Dehradun, India (snakesvishal@gmail.com; fergus.nature@gmail.com)

$\mathrm{T}$ The Oriental colubrid genus Coelognathus Fitzinger 1843 is represented by seven species of largely terrestrial snakes of which three, C. flavolineatus (Schlegel 1837), C. helena (Daudin 1803), and C. radiatus (Boie 1837), occur in India (Schulz 2013). Coelognathus radiatus is widely distributed across southern Asia, having been recorded from Indonesia, Malaysia, Singapore, Burma, Thailand, Cambodia, Vietnam, Nepal (Pandey 2011), Bangladesh (Mahony and Reza 2008), and India. In India, these snakes occur in apparently disjunct populations from Uttarakhand (Joshi 2013) to Arunachal
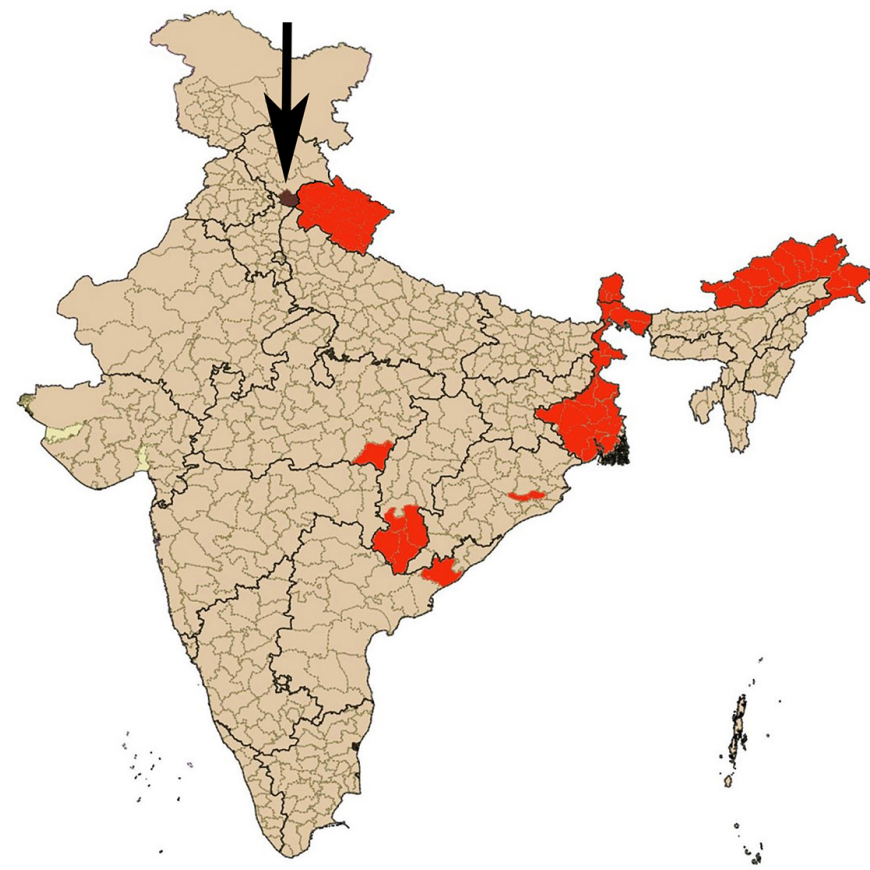

Fig. 1. Map showing the distribution of the Copper-headed Trinket Snake (Coelognathus radiatus) in India (red) and the range extension (brown and indicated by the arrow) in Himachal Pradesh.

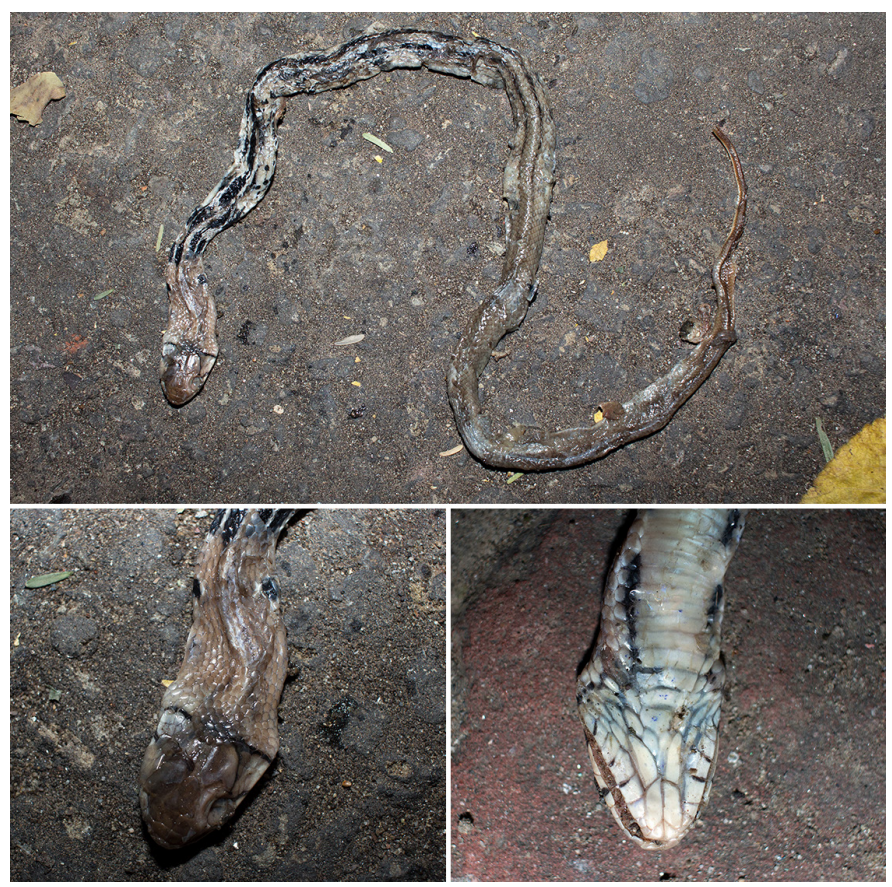

Fig. 2. A road killed Copper-headed Trinket Snake (Coelognathus radiatus) from Naraini Village, Solan District, Himachal Pradesh, India. Photographs by Vishal Varma.

Pradesh (Whitaker and Captain 2008), West Bengal, and Sikkim, and in some parts of Madhya Pradesh (Kanha National Park; Thakur 2011). This species also has been documented from the Ananthagiri Hills in the Eastern Ghats of Telangana (Javed et al. 2010).

At $2227 \mathrm{~h}$ on 1 October 2018 during a field survey at Naraini Village, Solan District, Himachal Pradesh $\left(30.7761^{\circ} \mathrm{N}, 77.0196^{\circ} \mathrm{E} ; 878 \mathrm{~m}\right.$ asl; Fig. 1), we found a road-killed juvenile male Copper-headed Trinket Snake (Coelognathus radiatus) (total length $44.5 \mathrm{~cm}$; Fig. 2). The previous northwesternmost record of $C$. radiatus in India 
was from Dehradun District (Rajaji National Park) in Uttarakhand (Bhatnagar 1969; Joshi 2013). The new record reported herein extends the range of this species into the state of Himachal Pradesh and suggests that the natural distribution extends into the northwestern Shivalik Hills of India and adjacent Nepal.

\section{Literature Cited}

Bhatnagar, R.K. 1969. Extension of range of copperhead snake, Elaphe radiata Schlegel (Ophidia: Colubridae) to Doon valley and Doon Shiwaliks. Journal of the Bombay Natural History Society 66: 383.

Javed, S.M.M., F. Tampal, and C. Srinivasulu. 2010. First record of Coelognathus radiatus (Boie, 1827) (Reptilia: Colubridae) from the Ananthagiri Hills,
Eastern Ghats, India. Journal of Threatened Taxa 2010 2: 1172-1174.

Joshi, R. 2013. Reptilia, Squamata, Colubridae, Elaphe radiate (Boie, 1827): new range and habitat notes for Rajaji National Park, northwest India. Journal of Biology and Earth Sciences 3: 169-175.

Mahony, S. and A. Reza. 2008. A herpetofaunal collection from the Chittagong Hill tracts, Bangladesh, with two new species records for the country. Hamadryad 32: 45-56.

Pandey, D. 2011. Snakes in the vicinity of Chitwan National Park, Nepal. Herpetological Conservation and Biology 7: 46-57.

Schulz, K.-D. 1996. A Monograph of the Colubrid Snakes of the Genus Elaphe Fitzinger. Koeltz Scientific Books, Havlíčkủv Brod, Czech Republic.

Thakur, S. 2011. A note on snakes of Kanha National Park and surrounding areas. Reptile Rap 11: 2-4.

Whitaker, R. and A. Captain. 2008. Snakes of India. The Field Guide. Draco Books, Chennai, India. 